\title{
Case Dosing Unit
}

National Cancer Institute

\section{Source}

National Cancer Institute. Case Dosing Unit. NCI Thesaurus. Code C62414.

A dosing unit equal to the amount of active ing redient(s) contained in a case. 